\title{
Correction: Effects of isotretinoin on new bone formation after maxillary sutural expansion
}

\author{
Musa Bulut ${ }^{1}$ ' Yasemin Nur Korkmaz ${ }^{1}$ Sevilay Erimsah² \\ Published online: 9 December 2020 \\ c) Springer Medizin Verlag GmbH, ein Teil von Springer Nature 2020
}

\section{Correction: Auswirkungen von Isotretinoin auf die Knochenneubildung nach maxillärer suturaler Expansion}

\section{Correction to:}

J Orofac Orthop (2020) 81:440-446

https://doi.org/10.1007/s00056-019-00209-2

The original version of this article unfortunately contained a mistake. The third bullet under the section Materials and Methods should read "Soybean oil (SOY) group: Soybean oil was administered via oral gavage $(\mathbf{2} \mathbf{~ m l} / \mathbf{k g})$ during the nursery period before expansion (an interval of 40 days), and during the expansion (period of 5 days) + retention period (period of 12 days - a total of 57 days)" instead of "Soybean oil (SOY) group: Soybean oil was administered via oral gavage $(0.2 \mathrm{ml} / \mathrm{kg})$ during the nursery period before expansion (an interval of 40 days), and during the expansion (period of 5 days) + retention period (period of 12 days - a total of 57 days)".

The authors apologize for the mistake.

Published online: 21 January 2020

(C) Springer Medizin Verlag GmbH, a part of Springer Nature 2019

The online version of the original article can be found under https://doi.org/10.1007/s00056-019-00209-2.

Musa Bulut, DDS, PhD

musabulut@gmail.com

1 Faculty of Dentistry, Department of Orthodontics, Bolu Abant Izzet Baysal University, Gölköy Yerleşkesi, 14030 Bolu, Turkey

2 Faculty of Medicine, Department of Histology and Embryology, Bolu Abant Izzet Baysal University, Bolu, Turkey 